\title{
'Is er invloed van de fysieke omgeving op het succes van een advies-op-maat interventie gericht op lichamelijke activiteit?'
}

\author{
K. Paulussen \\ Maastricht University \\ k.paulussen@studentmaastrichtuniversity.nl
}

\section{Samenvatting}

Achtergrond. Lichamelijke activiteit is een beschermende factor voor verschillende ziekten, zoals hart-en vaatziekten, kanker en diabetes. In Nederland beweegt een groot deel van de volwassenen te weinig, slechts $40 \%$ voldoet aan de Nederlandse norm voor gezond bewegen. Deze norm houdt in dat men minimaal 5 dagen per week, minstens 30 minuten matig intensief moet bewegen (bijvoorbeeld wandelen of fietsen). Het bevorderen van lichamelijke activiteit is een belangrijk onderwerp in de public health en er zijn al vele interventies ontwikkeld die zich richten op het stimuleren van lichamelijke activiteit. Tot nu toe zijn de effecten van dit soort interventies klein gebleken, daarom is het belangrijk dat wordt onderzocht onder welke omstandigheden interventies meer effectief kunnen zijn. De duidelijke associatie tussen de fysieke omgeving en lichamelijke activiteit is een reden waarom omgeving wellicht een beïnvloedende factor kan zijn voor een interventieeffect. Met de fysieke omgeving wordt bedoeld hoe de omgeving eruit ziet waarin een individu leeft, bijvoorbeeld de aanwezigheid van fiets/voetpaden of sportfaciliteiten. Het succes van een interventie zou ook gerelateerd kunnen zijn met opleiding, vanwege het feit dat laagopgeleiden vaker inactief zijn.

Doel. Onderzoeken of het effect van een advies-op-maat interventie wordt beïnvloed door de fysieke omgeving en opleidingsniveau. Het effect van de interventie wordt gemeten door het voldoen aan de beweegnorm en de intentie tot meer bewegen.

Methode. De studie werd uitgevoerd als een gerandomiseerde gecontroleerde trial (RCT) met een controle en een interventiegroep. De uitkomstmaten (voldoen aan de beweegnorm en intentie), kenmerken van de fysieke omgeving en sociaal demografische kenmerken zijn gemeten op de voormeting en na 1 maand follow-up, door middel van 
een vragenlijst. In totaal hebben 2159 respondenten, met een leeftijd van minimaal 30 jaar, deelgenomen aan het onderzoek. De data zijn geanalyseerd met behulp van meervoudige logistische en lineaire regressie. De uitkomstmaat werd hierbij gebruikt als de afhankelijke variabele en studiegroep en de interactie tussen omgeving/opleiding en groep werden gebruikt als onafhankelijke variabelen. Alle analyses werden uitgevoerd voor zowel de totale studiepopulatie als de risicogroep. De risicogroep werd gedefinieerd als niet voldoen aan de beweegnorm op de voormeting.

Resultaten. Erwas geen interactie met opleidingsniveau in zowel de totale studiepopulatie als in de risicogroep voor intentie om meer te gaan bewegen of voldoen aan de beweegnorm, wat impliceert dat er geen verschil was in interventie effect naar opleiding. $\mathrm{Er}$ is geen interactie (voor beide uitkomstmaten) gevonden met fysieke omgeving in zowel de totale studiepopulatie als in de risicogroep. De interventie heeft geresulteerd in een hoger percentage respondenten uit de risicogroep dat voldeed aan de beweegnorm (OR=1,34, 95\%=1,00-1,80).

Conclusie. In deze studie kon niet worden aangetoond dat de effecten van de interventie werden beïnvloed door fysieke omgevingsfactoren. De advies-op-maat interventie was effectief in het verhogen van lichamelijke activiteit bij mensen die op de voormeting niet aan de beweegnorm voldeden.

\section{Trefwoorden}

Lichamelijke activiteit, beweegnorm, public health, fysieke omgeving, advies-op-maat interventies, opleiding.

\section{Introductie}

Lichamelijke activiteit is een beschermende factor voor het ontstaan van verschillende ziekten, zoals coronaire hartziekten, type 2 diabetes en verschillende soorten kanker (Lee et al., 2012) en draagt bij aan een langere levensverwachting. Het blijkt dat een groot gedeelte van de Nederlandse bevolking te weinig beweegt, binnen de leeftijdsgroep 35 tot 54 jaar voldoet maar liefst 36\% niet aan de Nederlandse Norm Gezond Bewegen en binnen de groep 55 -plussers voldoet $40 \%$ niet aan de beweegnorm (Hildebrandt et al., 2012). Doordat een groot deel van de populatie in Nederland te weinig beweegt, kan lichamelijke inactiviteit gezien worden als een belangrijke issue binnen de public health en het is belangrijk meer lichamelijke activiteit te stimuleren.

Lichamelijke activiteit wordt gedefinieerd als 'elke krachtsinspanning van spieren die resulteert in meer energieverbruik dan in rustende toestand'. Een gebrek aan lichamelijke activiteit wordt vaak aangegeven als niet voldoen aan de Nederlandse Norm Gezond 
Bewegen (Nationaal Kompas, 2013). Deze norm kan gebruikt worden om na te gaan of mensen wel of niet voldoende bewegen en dus voldoen aan deze norm. Voor volwassenen houdt de beweegnorm in dat ze minimaal 5 dagen per week minstens een half uur matig intensief moeten bewegen (Hildebrandt, Ooijendijk \& Hopman-Rock, 2008). Onder matig intensief bewegen kan bijvoorbeeld stevig wandelen of fietsen worden verstaan (Kemper, Ooijendijk \& Stiggelbout, 2000).

De hoeveelheid beweging onder volwassenen kan verschillen tussen bepaalde groepen uit de populatie. Onder de laagopgeleiden bevinden zich duidelijk meer inactieven, namelijk $11,3 \%$ ten opzichte van $6,2 \%$ onder de hoogopgeleiden (Wendel-Vos et al., 2005).

Om lichamelijke activiteit te bevorderen is het belangrijk dat gebruikt wordt gemaakt van een interventie die veel mensen kan bereiken en die effectief is in het bevorderen van het gewenste gedrag. In het verleden zijn verschillende typen interventies gebruikt om lichamelijke activiteit te stimuleren. Zo werd vroeger bijvoorbeeld veel gebruik gemaakt van massa media interventies. Deze interventies speelden in op algemene determinanten en niet op specifieke determinanten die bij een specifiek individu van belang zijn (De Vries \& Brug,1999). Vanwege het feit dat massa media interventies inspelen op algemene determinanten blijken ze minder effectief te zijn. Interventies waarbij de informatie aangepast wordt aan het individu lijken effectiever te zijn dan interventies waarbij algemene informatie wordt gebruikt. Deelnemers aan een advies-op-maat interventie bleken na het gebruik van de interventie positiever over het nieuwe gedrag dan deelnemers aan een ander soort interventie (Kreuter, Bull, Clark \& Oswald, 1999).

In de meta-analyse van Krebs, Prochaska en Rossi (2010) zijn de effecten van 88 adviesop-maat interventies gericht op stoppen met roken, lichamelijke activiteit en voeding en borstkankerscreening geëvalueerd. Deze studie heeft laten zien dat advies-op-maat interventies de potentie hebben om lichamelijke activiteit te bevorderen. Na het volgen van advies-op-maat interventies voldeed $43 \%$ van de deelnemers aan de aanbevelingen voor gezond bewegen, terwijl dit bij de personen die geen interventie hadden gevolgd (controlegroep), slechts 34\% was (Krebs et al., 2010). Advies-op-maat interventies lijken ook invloed te hebben op het vergroten van een positieve intentie ten aanzien van beweging (Kreuter et al., 1999). Advies-op-maat interventies zijn dus effectieve interventies waar bovendien grote groepen mensen mee bereikt kunnen worden. Echter, de effecten van dit type interventie kunnen nog verhoogd worden. Ook kan onderzocht worden onder welke omstandigheden deze interventies meer of minder effectief kunnen zijn. Om inzicht te krijgen in de omstandigheden waaronder advies-op-maat interventies effectief kunnen zijn, wordt er in dit onderzoek gekeken naar het feit of een interventie effectiever is in een gunstige omgeving. In deze studie zal onderzocht worden wat de invloed van de fysieke 
omgeving is op het succes van een interventie die lichamelijke activiteit bevordert. Tevens zal worden gekeken naar de invloed van de interventie op de intentie van deelnemers om meer te gaan bewegen.

Uit huidige literatuur blijkt dat er veel evidence is voor een relatie van de fysieke omgeving met lichamelijke activiteit. Onderzoek laat zien dat toegang tot sportfaciliteiten en andere factoren van de fysieke omgeving (bijvoorbeeld verkeer, aanwezigheid van goede verlichting en voetpaden) factoren zijn die van invloed zijn op lichamelijke activiteit (Wendel-Vos, Droomers, Kremers, Brug \& van Lenthe, 2007). Onderzoek heeft ook aangetoond dat de kans dat mensen te voet naar hun werk gaan groter wordt naarmate de fysieke omgeving stimuleert om te bewegen (Craig, Browson, Cragg \& Dunn, 2002). De aanwezigheid van voorzieningen zoals winkels, school/werk, recreatie en andere openbare gelegenheden in de nabije omgeving speelt ook een belangrijke rol bij de keuze om wel of niet te gaan bewegen. Als dit soort voorzieningen zich in de nabije omgeving bevinden zullen mensen vaker van actief vervoer (zoals wandelen en fietsen) gebruik maken. Ook de aanwezig van voldoende sportvoorzieningen draagt bij aan de lichamelijke activiteit van mensen (Linger, Bakker, Bosscher \& ten Dam, 2010).

De duidelijke associatie tussen omgeving en lichamelijke activiteit is een reden waarom de omgeving wellicht een beïnvloedende factor kan zijn voor interventie-effecten, ook hiervoor zijn uit eerder onderzoek aanwijzingen. Er zijn enkele onderzoeken die een verband hebben aangetoond tussen de omgeving en het succes van een interventie, echter hebben deze onderzoeken zich gericht op voeding en niet op lichamelijke activiteit. Er is een studie uitgevoerd naar manieren waarop de omgeving het effect van een voedsel-interventie wijzigt. Onder deelnemers van de interventie die aangaven dat er weinig supermarkten in de nabije omgeving waren, steeg de groenten en fruitinname ook meer dan bij de mensen in de controlegroep (die ook aangaven dat er weinig supermarkten waren). Het resultaat van deze studie geeft dus aan dat de omgeving wel degelijk het succes van een interventie kan veranderen (Gustafson et al., 2012). Het onderzoek van Ezendam, Noordergraaf, Kroeze, Brug \& Oenema (2013) laat zien dat de aanwezigheid van groenten in huis gerelateerd is aan de groenteconsumptie. Pubers, bij wie altijd groenten in huis waren, bleken na de interventie meer groenten te gaan consumeren dan pubers bij wie niet altijd groenten in huis waren. De invloed van beschikbaarheid van gezond eten in huis wijzigt dus het effect van de interventie, dit geeft ook aan dat de omgeving het succes van een advies-op-maat interventie kan beïnvloeden (Ezendam et al., 2013).

De onderzoeksvragen die passen bij dit onderzoek luidt als volgt: 1) 'Heeft de fysieke omgeving invloed op het succes van een advies-op-maat interventie gericht op het bevorderen van lichamelijke activiteit op intentie en gedrag? en 2) Is er een verschil tussen 
mensen naar opleiding in de mate waarin de fysieke omgeving het interventie effect beïnvloedt?

\section{Materialen en methoden}

\section{Studiedesign}

De studie werd uitgevoerd als een gerandomiseerde gecontroleerde trial (RCT) met een interventie en een controlegroep. Metingen werden uitgevoerd op de voormeting (voorafgaand aan de interventie) en vier weken na de interventie. Er zijn twee uitkomstmaten gebruikt, namelijk voldoen aan de beweegnorm en het hebben van een intentie om meer te gaan bewegen.

\section{Deelnemers en werving}

Voor het onderzoek werden deelnemers geselecteerd, dit waren Nederlandse volwassenen van minimaal 30 jaar oud. Deelnemers dienden tevens te beschikken over begrip van de Nederlandse taal en goede internetvaardigheden.

\section{Procedure}

Door middel van een e-mail werden de deelnemers uitgenodigd voor deelname aan de studie. In deze e-mail stond de inhoud en het doel van de studie uitgelegd, evenals hoe de randomisatie procedure in zijn werk gaat. Aan de email werd een baselinevragenlijst toegevoegd, indien uitgenodigden deze vragenlijst compleet ingevuld hadden, bevestigden zij deelname aan de studie. Respondenten werden random toegewezen aan de interventie en controlegroep. De onderzoekers waren geblindeerd voor de studieconditie van de respondenten gedurende de gehele interventieperiode. Na het compleet invullen van de baseline-vragenlijst kregen de deelnemers uit de interventiegroep toegang tot de website van de interventie, dit gebeurde na 3 weken (via e-mail). Vier weken lang konden zij gebruik maken van deze website, vervolgens werd via de e-mail de follow-up vragenlijst verspreid.

De interventie bestaat uit een website met advies-op-maat informatie over lichamelijke activiteit, roken en inname van verzadigde vetten. Deze studie gaat echter enkel over lichamelijke activiteit. Deelnemers van de interventie konden inloggen op de website en kregen hier alle informatie over de interventie te lezen. Een korte vragenlijst over lichamelijke activiteit, voeding en roken werd gebruikt om te bepalen welk onderdeel van de interventie het meest geschikt was voor deze respondent. Mensen die te weinig bleken te bewegen werden doorverwezen naar de beweegmodule. De modules zijn gebaseerd 
op het Precaution Adoption Process Model (Weinstein, 1988). Het Precaution Adoption Process model beschrijft dat gedragsverandering een proces is waarin verschillende stappen worden doorlopen. In deze interventie werd bekeken in welke fase deelnemers zich bevinden en wordt geprobeerd determinanten te beïnvloeden die zorgen dat mensen naar de volgende fase gaan. De eerste fase in het model is dat mensen geen besef hebben van het probleem van lichamelijke inactiviteit, bij deze mensen werd geprobeerd om ze te bewust te maken van het eigen risicogedrag (door middel van feedback op dit gedrag), terwijl bij mensen die wel bekend zijn met het probleem, maar niet daadwerkelijk meer willen gaan bewegen, werd geprobeerd de intentie te verbeteren. Mensen werden dan bijvoorbeeld verwezen naar een module over attitude, om nog meer overtuigd te raken van het belang van meer bewegen. Indien mensen aangaven van plan te zijn om meer te gaan bewegen (en dus een positieve intentie hebben) maar deze intentie nog niet hebben uitgevoerd doordat ze niet weten hoe ze dit aan moeten pakken, werden ze verwezen naar een module waarin ze feedback krijgen om de eigen-effectiviteit te verhogen, daar kon vervolgens een actieplan worden gemaakt.

\section{Metingen en meetinstrumenten}

\section{Gedrag}

Lichamelijke activiteit werd gemeten door middel van een verkorte versie van de International Physical Activity Questionnaire (IPAQ). De vragenlijst meet de lichamelijke activiteit in de afgelopen zeven dagen. De deelnemers werd gevraagd om aan te geven op hoeveel dagen ze in de afgelopen zeven dagen hadden gewandeld of zware ofmiddelzware activiteiten hadden uitgevoerd. Daarnaast konden ze invullen hoeveel tijd per dag ze aan die activiteit hadden besteed. Op basis van deze vragen werd een gemiddeld aantal minuten per dag berekend dat werd bewogen. Vanuit het gemiddeld aantal minuten per dag werd een dichotome variabele berekend die aangeeft of mensen wel/niet voldeden aan de beweegnorm.

Op basis van studies naar de validiteit van dit meetinstrument kan worden aangenomen dat IPAO een acceptabele validiteit heeft als het gaat om het vaststellen van lichamelijke activiteit bij gezonde volwassenen. Een betrouwbaarheidsanalyse voor de verkorte versie van IPAQ, die in dit onderzoek werd gebruikt, laat een Spearman's correlatie van o,76 zien. De betrouwbaarheid is gemeten over een periode van 11 weken (tussen de vragenlijst op de voor en de nameting zat 11 weken). Een correlatie van 0,76 kan als betrouwbaar worden ervaren (Hagströmer, Oja \& Sjöström, 2006).

Één vraag uit de vragenlijst werd gebruikt om intentie te meten, er werd aan de 
deelnemers gevraagd of zij van plan waren om meer te gaan bewegen. Deze vraag werd beantwoord op een 7-punt-schaal (lopend van zeer zeker niet tot zeer zeker wel). Een vragenlijst met dertien items werd gebruikt voor het meten van omgevingsfactoren. In deze vragenlijst werd gevraagd naar voorzieningen in de omgeving (zoals voldoende trottoirs en fietspaden, sportfaciliteiten, bus/tramhaltes en winkels op loopafstand). Tevens werd gevraagd naar de veiligheid van de omgeving (zoals het gevoel van veiligheid in de buurt, aanwezigheid van straatverlichting en druk verkeer). Tot slot werden vragen gesteld over het feit of de respondenten hun omvgeving aantrekkelijk en geschikt vinden om te wandelen, fietsen of sporten en of de omgeving in de buurt ligt van bossen en/ of parken. Deze vragen konden worden beantwoord op een 5-punt-schaal lopend van helemaal mee eens tot helemaal mee oneens.

\section{Analyses}

De studiepopulatie is beschreven door middel van beschrijvende statistiek (gemiddelden, minimum, maximum etc.). Verschillen tussen de controle en interventiegroep op de baseline werden getest door middel van logistische regressie. Er werd hierbij gekeken of er tussen de twee groepen verschillen waren naar geslacht, leeftijd, het wel/niet voldoen aan de beweegnorm bij de baselinemeting, omgeving, opleiding en het percentage uitval op de nameting. Tevens is er gekeken of mensen die wel/niet in de analyse zijn meegenomen van elkaar verschilden wat betreft geslacht, leeftijd, het wel/niet voldoen aan de beweegnorm bij de baselinemeting, omgeving en opleiding. Ook deze analyse is uitgevoerd door middel van logistische regressie.

Om te onderzoeken of het interventie effect (met voldoen aan de beweegnorm als uitkomstmaat) werd beïnvloed door factoren uit de omgeving werd een logistische regressie analyse uitgevoerd. Voldoen aan de norm op de nameting werd hierbij gebruikt als afhankelijke variabele en groep en de interactie group $x$ omgeving werden hier als onafhankelijke variabelen gebruikt. Wanneer er een significant interactie effect werd gevonden, werden er gestratificeerde analyses worden uitgevoerd. Tevens werd er onderzocht of er een verschil is tussen mensen naar opleiding in de mate waarin de fysieke omgeving het interventie effect kan beïnvloeden. Om dit aan te tonen werd eerst onderzocht of er een significante interactie is tussen interventie en opleiding, dit werd gedaan door middel van een logistische regressie analyse met voldoen aan de norm op de nameting als afhankelijke variabele en groep en de interactie groep $\mathrm{x}$ opleiding als onafhankelijke variabelen. Wanneer er een significante interactie werd gevonden, werden er opnieuw gestratificeerde analyses voor verschillende groepen opleiding worden uitgevoerd. Naast de uitkomstmaat voldoen aan de beweegnorm werden bovenstaande 
analyses nog eens uitgevoerd met intentie tot meer bewegen als uitkomstmaat (enkel wordt voor deze uitkomstmaat lineaire in plaats van logistische regressie gebruikt). Bovenstaande analyses (voor beide uitkomstmaten) werden nogmaals uitgevoerd voor de risicogroep (de deelnemers die op de voormeting niet aan de beweegnorm voldeden). De analyses zijn uitgevoerd met SPSS IBM statistics version 21.0, het significantie level was 0,05 en 0,10 voor het toetsen van de interacties.

\section{Resultaten}

\section{Deelnemers en respons}

In totaal deden 2159 deelnemers mee aan de studie, waarvan 1079 personen werden toegewezen aan de controlegroep en 1080 personen aan de interventiegroep. Deelnemers werden geselecteerd voor de uiteindelijke analyses indien 100\% van de vragen op zowel de vragenlijst van de voormeting als die van de nameting werd ingevuld (complete cases). De controlegroep bij de analyses bestond hierdoor uit 890 respondenten en de interventiegroep uit 827 respondenten. De deelnemers uit de controle- en interventiegroep verschilden niet significant van elkaar wat betreft leeftijd, geslacht, opleiding, uitval op de nameting, omgeving, intentie en het voldoen aan de beweegnorm op de voormeting.

\section{Karakteristieken van de deelnemers}

De gemiddelde leeftijd van de geanalyseerde respondenten was 43,7 jaar oud $(S D=10,1)$ en $53,2 \%$ was man. Bijna een derde (26,8\%) van de respondenten was laagopgeleid, $32,7 \%$ was midden opgeleid en het grootste deel van de studiepopulatie (40,5\%) was hoogopgeleid. Bij de baseline voldeed $43,7 \%$ van de respondenten aan de beweegnorm en de gemiddelde score voor de omgevingsvariabelen was 2,07 ( $S D=0,54$, range $=1,00-4,62)$, wat betekent dat de respondenten hun omgeving gemiddeld als gunstig ervaren. De gemiddelde waarde van intentie op de voormeting was $0,43(S D=1,20)$ en op de nameting was deze waarde $0,33(S D=1,18)$. In de totale studiepopulatie voldeed op de nameting $46,7 \%$ aan de beweegnorm. Na de interventieperiode voldeed in de controlegroep $42,7 \%$ aan de beweegnorm, terwijl dit op de voormeting $43,4 \%$ was. In de interventiegroep voldeed $46,7 \%$ aan de beweegnorm, terwijl dit op de voormeting $44,1 \%$ was.

\section{Resultaten in de totale studiepopulatie}

Er is geen significante interactie gevonden tussen opleidingsniveau van de respondenten en het voldoen aan de beweegnorm op de nameting ( $\mathrm{OR}=1,20,95 \% \mathrm{Cl}=0,76-1,90)$. Tevens is er geen significant interactie gevonden tussen de fysieke omgeving en het voldoen aan de beweegnorm op de nameting ( $\mathrm{OR}=1,18,95 \% \mathrm{Cl}=0,87-1,59)$ (Tabel 1). 
$\mathrm{Er}$ is geen interactie aanwezig tussen opleidingsniveau en de intentie op de nameting $(\mathrm{P}=0,603,95 \% \mathrm{Cl}=-0,15-0,08)$. De interventie heeft niet geresulteerd in een verandering in intentie op de nameting, ten opzichte van de voormeting $(P=0,362,95 \% \mathrm{Cl}=-0,23-0,36)$. Behalve het feit dat er geen significant effect was van de interventie op de intentie, is er ook geen significante interactie met omgeving $(\mathrm{P}=0,222,95 \% \mathrm{Cl}=-0,30-0,05)($ Tabel 1$)$.

Tabel 1. Uitkomsten van de regressie analyses voor de totale populatie (gemiddelden, OR, B-waarden, $95 \% \mathrm{Cl}$ ) met als uitkomsten voldoen aan de beweegnorm en intentie en met de omgevingsvariabele en opleidingsniveau als onafhankelijke variabele.

\begin{tabular}{|c|c|c|c|c|c|c|c|}
\hline \multicolumn{8}{|c|}{ Totale studiepopulatie $(\mathrm{N}=1717)^{\mathrm{a}}$} \\
\hline & \multicolumn{2}{|c|}{ Baseline } & \multicolumn{2}{|c|}{ Posttest } & \multicolumn{3}{|c|}{ OR/b $(95 \% \mathrm{Cl})$} \\
\hline & $\begin{array}{c}\mathrm{I} \\
(\mathrm{N}=827)\end{array}$ & $\begin{array}{c}C \\
(N=890)\end{array}$ & $\begin{array}{c}\mathrm{I} \\
(\mathrm{N}=827)\end{array}$ & $\begin{array}{c}C \\
(N=890)\end{array}$ & $\begin{array}{l}\text { Interactie* } \\
\text { opleiding }^{\mathrm{b}}\end{array}$ & $\begin{array}{l}\text { Interactie* } \\
\text { opleiding }\end{array}$ & Groep $^{d}$ \\
\hline $\begin{array}{l}\text { Voldoen aan } \\
\text { beweegnorm } \\
(\%)\end{array}$ & 44,1 & 43,4 & 47,0 & 44,0 & $\begin{array}{c}1,20 \\
(0,76-1,90)\end{array}$ & $\begin{array}{c}1,18 \\
(0,87-1,59)\end{array}$ & $\begin{array}{c}1,17 \\
(0,97-1,40)\end{array}$ \\
\hline Intentie & 0,46 & 0,40 & 0,36 & 0,30 & $\begin{array}{c}0,06 \\
(-0,87-1,59)\end{array}$ & $\begin{array}{c}-0,13 \\
(-0,15-0,08)\end{array}$ & $\begin{array}{c}-0,04 \\
(-0,15-0,08)\end{array}$ \\
\hline
\end{tabular}

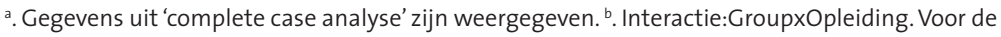
uitkomstmaat voldoen aan de norm is logistische regressie uitgevoerd en wordt dus het OR en het $95 \% \mathrm{Cl}$ weergegeven, voor de uitkomstmaat intentie is lineaire regressie uitgevoerd en wordt dus de B-waarde en het $95 \% \mathrm{Cl}$ weergegeven. c. Interactie:GrouepxOmgeving. Voor de uitkomstmaat voldoen aan de norm is logistische regressie uitgevoerd en wordt dus het OR en het $95 \% \mathrm{Cl}$ weergegeven, voor de uitkomstmaat intentie is lineaire regressie uitgevoerd en wordt dus de B-waarde en het $95 \% \mathrm{Cl}$ weergegeven. ${ }^{\mathrm{d}}$. De invloed van de studiegroep op de uitkomstmaat (voldoen aan de norm of intentie) is hier getoetst.
}

\section{Resultaten in de risicogroep}

De interactie met omgeving is niet significant gebleken ( $O R=1,20,95 \%=0,76-1,89$ ), net als de interactie met opleiding $(\mathrm{OR}=1,18(0,87-1,61)$. Binnen deze risicogroep heeft de interventie echter wel geleid tot een significant verschil in lichamelijke activiteit $(O R=1,34$, 95\% Cl=1,00-1,80) (Tabel 2).

In de risicogroep zijn geen significante effecten gevonden indien er wordt gekeken naar de invloed van de interventie, omgeving en opleiding op de intentie op de nameting. Er is geen intereactie aanwezig met opleiding $(\mathrm{P}=0,579,95 \% \mathrm{Cl}=-0,15-0,30)$ en er is ook geen interactie met omgeving $(P=0,485,95 \% \mathrm{Cl}=0,15-0,30)$. De interventie heeft ook niet geleid tot een significant verschil in intentie $(\mathrm{P}=0,832,95 \% \mathrm{Cl}=-0,17-0,14)$ (Tabel 2$)$. 
Tabel 2. Uitkomsten van de regressie analyses voor de risicogroep (gemiddelden, OR, B-waarden, 95\% CI)

\begin{tabular}{|c|c|c|c|c|c|c|c|}
\hline \multicolumn{8}{|c|}{ Risicogroep $(\mathrm{N}=966)^{\mathrm{a}}$} \\
\hline & \multicolumn{2}{|c|}{ Baseline } & \multicolumn{2}{|c|}{ Posttest } & \multicolumn{3}{|c|}{ OR/b (95\% Cl) } \\
\hline & $\begin{array}{c}\mathrm{I} \\
(\mathrm{N}=462)\end{array}$ & $\begin{array}{c}C \\
(N=504)\end{array}$ & $\begin{array}{c}\mathrm{I} \\
(\mathrm{N}=462)\end{array}$ & $\begin{array}{c}C \\
(N=504)\end{array}$ & $\begin{array}{l}\text { Interactie* } \\
\text { opleiding }^{\text {b }}\end{array}$ & $\begin{array}{l}\text { Interactie* } \\
\text { opleiding }\end{array}$ & Groep $^{d}$ \\
\hline $\begin{array}{l}\text { Voldoen aan } \\
\text { beweegnorm } \\
\text { (\%) }\end{array}$ & 0 & 0 & 27,5 & 22,0 & $\begin{array}{c}1,18(0,87- \\
1,61)\end{array}$ & $\begin{array}{c}1,20(0,76- \\
1,89)\end{array}$ & $\begin{array}{c}1,34(1,00- \\
1,80)\end{array}$ \\
\hline Intentie & 0,49 & 0,47 & 0,37 & 0,39 & $\begin{array}{c}-0,02(-0,15- \\
0,30)\end{array}$ & $\begin{array}{c}-0,10(-0,34- \\
0,14)\end{array}$ & $\begin{array}{c}-0,08(-0,17- \\
0,14)\end{array}$ \\
\hline
\end{tabular}

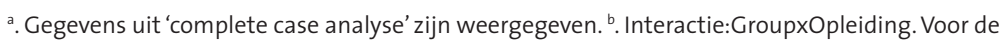
uitkomstmaat voldoen aan de norm is logistische regressie uitgevoerd en wordt dus het OR en het $95 \% \mathrm{Cl}$ weergegeven, voor de uitkomstmaat intentie is lineaire regressie uitgevoerd en wordt dus de B-waarde en het $95 \% \mathrm{Cl}$ weergegeven. c. Interactie:GrouepxOmgeving. Voor de uitkomstmaat voldoen aan de norm is logistische regressie uitgevoerd en wordt dus het OR en het $95 \% \mathrm{Cl}$ weergegeven, voor de uitkomstmaat intentie is lineaire regressie uitgevoerd en wordt dus de B-waarde en het $95 \% \mathrm{Cl}$ weergegeven. ${ }^{\mathrm{d}}$. De invloed van de studiegroep op de uitkomstmaat (voldoen aan de norm of intentie) is hier getoetst.

\section{Discussie/conclusie}

Het belangrijkste doel van dit onderzoek was om na te gaan of de fysieke omgeving invloed heeft op het succes van een beweegadvies-op-maat interventie op intentie om meer te gaan bewegen en beweging. Er zijn geen aanwijzingen gevonden voor het feit dat de fysieke omgeving, zoals gemeten in dit onderzoek, invloed zou hebben op het succes van de advies-op-maat interventie voor beide uitkomstmaten, in zowel de totale studiepopulatie als in de risicogroep. Er is gebleken dat er geen verschil is in het effect van de interventie voor beide uitkomstmaten bij mensen uit verschillende opleidingsgroepen, voor zowel de totale studiepopulatie als de risicogroep. De advies-op-maat interventie heeft echter wel geresulteerd in een significant hoger percentage respondenten uit de risicogroep dat op de nameting voldeed aan de beweegnorm. In de totale studiepopulatie werd voor beide uitkomstmaten geen interventie effect gevonden.

De bevindingen in het onderzoek komen niet overeen met wat verwacht werd voorafgaand aan het onderzoek. De fysieke omgeving blijkt namelijk wel degelijk een invloed te hebben op lichamelijke activiteit, daarom valt ook te verwachten dat de fysieke omgeving een rol speelt bij het wel/niet aanslaan van een interventie die de lichamelijke activiteit wil verhogen. Op basis van eerder onderzoek zou ook verwacht kunnen worden dat de fysieke omgeving wel degelijk invloed heeft op het succes van een advies-op-maat interventie. Uit eerdere onderzoeken blijkt namelijk dat er wel aanwijzingen zijn dat de omgeving van 
een individu het succes van een advies-op-maat interventie kan beïnvloeden (Gustafson et al., 2012, Ezendam et al.,2013).

Dit onderzoek heeft gekeken naar 13 factoren uit de omgeving. Deze 13 factoren zijn andere typen factoren dan waar in voorgaand beschreven onderzoek naar is gekeken. In deze onderzoeken is gekeken naar omgevingsfactoren die bijvoorbeeld dichter bij de thuissituatie liggen dan de factoren die in deze studie zijn gemeten. In het onderzoek van Ezendam is gekeken naar de aanwezigheid van groenten- en fruit in huis, dit is een determinant die veel dichter bij de thuissituatie staat dan factoren als bijvoorbeeld de aanwezigheid van voet en fietspaden en sportfaciliteiten. Het onderzoek van Gustafson heeft aangetoond dat de aanwezigheid van groenten en fruit in de supermarkt geassocieerd is met het interventie-effect, ook dit is een ander soort determinant dan die in dit onderzoek zijn meegenomen.

Het zou zo kunnen zijn dat dit onderzoek geen effect heeft aangetoond, omdat de omgeving waar naar is gekeken te ver van het individu afstaat. Het blijkt zo te zijn dat omgevingsfactoren uit de thuisomgeving ook invloed hebben op lichamelijke activiteit. Onderzoek heeft namelijk aangetoond dat omgevingsfactoren uit de thuisomgeving invloed kunnen hebben op lichamelijke activiteit. Zo blijkt dat indien mensen in het bezit waren van sportuitrusting, bleken zij meer lichamelijke activiteit te vertonen dan mensen die geen sportuitrusting in huis hadden (Wendel-Vos, Droomers, Kremers, Brug \& van Lenthe, 2007). De associatie die in dit onderzoek is gevonden lijkt erg sterk, daarom lijkt ook een relatie van dit soort omgevingsdeterminanten met het succes van een interventie aannemelijk.

Een andere verklaring waarom in voorgaand onderzoek wel effecten zijn gevonden en in deze studie niet zou kunnen zijn dat voorgaande studies zich hebben gericht op totaal verschillende doelgroepen. Het onderzoek van Gustafson et al (2012) is gericht op vrouwen met een laag inkomen, terwijl in deze studie zowel mannen als vrouwen zijn meegekomen en deze studie is ook niet specifiek gericht op mensen met een laag inkomen. In deze studie is wel gekeken naar verschillen onder mensen met verschillende opleidingsniveaus, wat ook een indicator is van sociaaleconomische status. Het onderzoek laat echter zien dat er geen verschillen zijn naar opleiding. Over het inkomen is in deze studie geen informatie beschikbaar. Het onderzoek van Gustafson et al (2012) heeft tevens respondenten geselecteerd met een te hoge BMI (minimaal 27,5) die zelf al graag wilden afvallen. Het onderzoek van Ezendam et al (2013) heeft de invloed van de fysieke omgeving bij adolescenten bekeken, terwijl dit onderzoek zich op volwassenen heeft gericht. Wellicht dat de invloed van de fysieke omgeving anders is voor deze verschillende doelgroepen, bijvoorbeeld dat de fysieke omgeving meer van invloed is bij vrouwen, bij mensen met een 
te hoge BMI of bij adolescenten. Voor toekomstig onderzoek is het raadzaam om dit soort kenmerken mee te nemen en een specifiekere doelgroep te onderzoeken.

Een andere mogelijke verklaring voor het ontbreken van een effect is dat er weinig variatie was in de scores op de omgevingsvragenlijst. De gemiddelde waarden van de omgeving in de totale populatie was 2,06. Deze waarde duidt op een relatief gunstige fysieke omgeving, omdat een waarde van 2 duidt op het antwoord 'mee eens'. Als gekeken wordt naar de verdeling van de antwoorden van de deelnemers, blijkt dat maar een heel klein deel van de deelnemers heeft aangegeven zijn/haar eigen omgeving als ongunstig te ervaren (slechts 19 deelnemers scoren hoger dan 3,5 op de variabele). In deze variabele zit te weinig variatie, wat er toe zou kunnen leiden dat er geen effect van de fysieke omgeving is gevonden. Een groter contrast in de omgeving zou beter inzicht kunnen geven in of de fysieke omgeving wel/niet invloed kan hebben op het interventie effect.

In totaal zijn er dertien vragen gesteld over de fysieke omgeving, die vervolgens samen zijn gevoegd in een variabele. Uit het onderzoek van Duncan, Spence \& Mummery(2005) blijkt dat niet elk kenmerk van de fysieke omgeving daadwerkelijk invloed heeft op lichamelijke activiteit. De onderzoekers lieten zien dat de aanwezigheid van sportfaciliteiten in de nabije omgeving, de aanwezigheid van voetpaden, winkels en andere diensten en het ontbreken van druk verkeer leiden tot meer lichamelijke activiteit, maar dat er geen associatie is tussen lichamelijke activiteit en veiligheid/straatverlichting in de omgeving (Duncan, Spence \& Mummery, 2005). Voor vervolgonderzoek zou het dus raadzaam zijn om ook de kijken naar andere aspecten van de fysieke omgeving en deze aspecten apart te analyseren.

Vanwege het feit dat eerder soortgelijk onderzoek heeft aangetoond dat omgevingsfactoren die dicht bij de thuisomgeving liggen geassocieerd kunnen zijn met het effect van een advies-op-maat interventie en vanwege het feit dat onderzoek heeft laten zien dat dit soort determinanten samenhangen met lichamelijke activiteit, is het voor vervolgonderzoek een aanbeveling dat het zich gaat richten op omgevingsfactoren dicht bij de thuissituatie, zoals bijvoorbeeld de aanwezigheid van sportkleding. Bovendien zou voor vervolgonderzoek meer informatie aanwezig moeten zijn over de validiteit van het meetinstrument om fysieke omgeving te meten. Tevens is het van belang dat de invloed van de omgeving wordt getest bij een zeer effectieve advies-op-maat interventie.

Voor vervolgonderzoek is het noodzakelijk dat meer mensen geselecteerd worden met een ongunstige omgeving, dit zou bijvoorbeeld kunnen door mensen te benaderen die leven in wijken/steden waarvan bekend is dat de fysieke omgeving ongunstig is ingericht. De onderzoekspopulatie bestaat ook maar voor ongeveer een kwart uit mensen die laag opgeleid zijn, voor vervolgonderzoek is het ook belangrijk dat ongeveer de helft van de 
mensen laag opgeleid is en de andere helft van de mensen hoog opgeleid. Om dit voor elkaar te krijgen in de onderzoekspopulatie kan dezelfde methode worden toegepast als bij het verkrijgen van meer mensen met een ongunstige fysieke omgeving.

Voor nu lijkt er geen effect te zijn van (fysieke) omgeving op het succes van een adviesop-maat interventie, echter kent dit onderzoek enkele beperkingen en zijn er een aantal verklaringen te bedenken, die ervoor zouden kunnen zorgen dat het effect van de omgeving onderschat wordt. Voor vervolgonderzoek is het raadzaam rekening te houden met de beperkingen en verklaringen. Wellicht dat vervolgonderzoek dan wel een effect kan laten zien van omgeving op het succes van advies-op-maat interventies, of kan er na vervolgonderzoek worden uitgesloten dat er een relatie is tussen de omgeving van een individu en het succes van een advies-op-maat interventie.

\section{Rol van de student}

Kim Paulussen is een bachelorstudent gezondheidswetenschappen (major preventie \& gezondheid). Onder toezicht van Anke Oenema is dit onderzoek uitgevoerd. Het onderwerp is voorgesteld door de begeleider en het design van de interventie en de vragenlijst is ook samengesteld door de begeleider. Het analyseren van de resultaten, het trekken van de conclusies en het schrijven van de gehele thesis is uitgevoerd door de student.

\section{Referenties}

1. Craig, C. L. , Brownson, R. C., Cragg, S. E. , \& Dunn, A. L. (2002). Exploring the effect of the environment on physical activity: a study examining walking to work. American journal of preventive medicine, 23(2), 36-43.

2. Duncan, M. J., Spence, J. C., \& Mummery, W. K. (2005). Perceived environment and physical activity: a meta-analysis of selected environmental characteristics. International Journal of Behavioral Nutrition and Physical Activity, 2(1), 11.

3. Ezendam, N. P. M. , Noordegraaf, V. S. A. , Kroeze, W. , Brug, J. , \& Oenema, A. (2013). Process evaluation of FATaintPHAT, a computer-tailored intervention to prevent excessive weight gain among Dutch adolescents. Health promotion international, 28(1), 26-35.

4. Gustafson, A. A. , Sharkey, J. , Samuel-Hodge, C. D. , Jones-Smith, J. C. , Cai, J. , \& Ammerman, A. S. (2012) Food Store Environment Modifies Intervention Effect on Fruit and Vegetable Intake among Low-Income Women in North Carolina. Journal of nutrition and metabolism.

5. Hagströmer, M. , Oja, P. , \& Sjöström, M. (2006). The International Physical Activity QQuestionnaire (IPAO): a study of concurrent and construct validity. Public health nutrition, 9(06), 755-762.

6. Hildebrandt, V. H. , Ooijendijk, W. T. M. , \& Hopman-Rock, M. (2008). Bewegen en Gezondheid 2006/2007. Leiden: TNO Kwaliteit van Leven.

7. Kemper, H.G.C. , Ooijendijk, W.T.M. , \& Stiggelbout, M. (200o). Consensus over de Nederlandse Norm voor Gezond bewegen. Tijdschrift Sociale Gezondheidszorg.

8. Kreuter, M. W., Bull, F. C., Clark, E. M., \& Oswald, D. L. (1999). Understanding how people process health information: a comparison of tailored and nontailored weight-loss materials. Health Psychology, $18(5), 487$. 
9. Lee, I. M., Shiroma, E. J. , Lobelo, F., Puska. P., Blair, S. N. , \& Katzmarzyk, P. T. (2012). Effect of physical activity on major non-communicable diseases worldwide: an analysis of burden of disease and life expectancy. The Lancet.

10. De Vries, H. , \& Brug, J. (1999). Computer-tailored intervention motivating people to adopt health promoting behaviors: introduction to a new approach. Patient educ couns, 36(2), 99-105.

11. Weinstein, N.D. (1998). The precaution adoption process. Health psychology, 7(4), 255).

12. Wendel-Vos, G. C. W. , Ooijendijk, W. T. M. , Van Baal, P. H. M. , Storm, I. , Vijgen, S. M. C. , Jans, M. , \& Bemelmans, W. J. E. (2005). Kosteneffectiviteit en gezondheidswinst van behalen beleidsdoelen bewegen en overgewicht-Onderbouwing Nationaal Actieplan Sport en Bewegen.

13. Wendel-Vos, W.M.S.J.F, , Droomers, M., Kremers, S., Brug, J., \& van Lenthe, F. (2007). Potential environmental determinants of physical activity in adults: a systematic review. Obesity reviews, 8(5), 425-440. 